Rassomakhina Olga, $\mathrm{PhD}$ (Law Sciences), Associate Professor, Kyiv National University of Trade and Economics, 19, Kyoto str., Kyiv, 02156, Ukraine

ORCID: 0000-0003-2862-8169

\title{
TRADE MARK INFRINGEMENT LIABILITY ON THE INTERNET: ACTUAL PROBLEMS OF LEGAL REGULATION IN UKRAINE
}

In the article the author considers current issues of trademark protection on the Internet, existing types of rights violations and forms of liability for them, and identifies the existing mechanisms of protection of trademarks rights and directions of their improvement, that are actual for Ukraine.

Keywords: sign, trademark, Internet, legal protection of trademarks, infringement of trademarks rights on the Internet.

Рассомахіна Ольга. Захист торговельних марок в Інтернеті: актуальні проблеми правового регулювання в Украӥні.

У статті розглядаються актуальні проблеми захисту торговельних марок в Інтернет, існуючі види порушень прав на торговельні марки в Інтернет та форми відповідальності за них, а також визначаються існуючі механізми охорони ци захисту прав на торговельні марки в Інтернет та напрями їх вдосконалення, що є актуальні для України.

Ключові слова: торговельна марка, Інтернет, правова охорона торговельних марок, порушення прав на торговельні марки в Інтернет.

Relevance of research topic. In the conditions of development of market relations, the proper realization of intellectual property rights on trademarks is considered as an important factor of increasing the competitiveness of products, protection against unfair competition and creates opportunities for additional profits.

The existing laws on trademark protection in Ukraine, which define legal notions, forms and types of use of trademarks, although they take into account the sphere of Internet, and are sufficient to protect against infringement on the Internet, they are not sufficiently precise and detailed in terms of its content, relevant to the field of Internet. Thus, the legislation does not define the forms and types of use of trademarks on the Internet, the concept of proper, honest, nominal and descriptive use of trademarks on the Internet, the legislation does not specify the types of trademark infringements and methods of their protection on the Internet, which makes the 
procedure for the realization of trademark rights by the subjects of rights in our country more complicated. Therefore, one of the tasks of the legislative work in the field of trademark legal protection is to eliminate the deficiencies in the legal regulation and to establish the rules, defining the conditions of use and legal protection of trademarks on the Internet.

Today, Internet has become the cause of various infringements of rights and interests of trademark owners, in particular through the registration and use of them as domain names, creation of websites and use on them different designations and signs, use of trademarks as part of the meta tags, hyperlinks, spam, banners, carrying out various acts of unfair competition, through the use of trade mark as keywords and by other actions. The use of trademarks on the Internet gives rise to many conflicts, regarding the validity of the use of trademarks on the Internet in various forms and ways; by committing acts that constitute offenses, such as misrepresentation or confusion, dilution; it can be the basis for a variety of conflicts between domain name and trademark rights, including cyberpiracy, cybersquatting.

Thus, The Internet has created many problems. related to the legislation on the protection of trademarks. One of them is the problem of identifying the person, responsible for the offense. Many issues are related to the commercial use of trademarks on the Internet, such as the direct trade of goods and services on the Internet.

In general, these issues relate to the definition of how branding strategy, outside the Internet, can be extended to the sphere of Internet.

The study of legal regulation of trademarks protection on the Internet shows, that there is no special legislation for the protection of trademarks on the Internet at the international level as a whole, but in this area there are norms of soft law and the various instruments (different standards, standard contracts, legal constructions and models etc.).

It should be noted, that trademark rights are territorially restricted, while the Internet does not have such restrictions, so, the use of trademarks on the Internet is often contrary to the principle of territoriality and specialization, applicable to trademarks protection. Combating trademark infringement on the Internet is now a priority in many countries. This topic has also become relevant in Ukraine, in particular in connection with the legislative work on amending the legislation in the field of protection of intellectual property.

Problems of protection of signs on the Internet have been investigated within the WIPO framework, have been the subject of discussion in public authorities and public organizations, and have been mentioned in the scientific works of a large number of national and foreign scientists.

Formulation of the problem. However, the consideration of legislative regulation and practice of applying trademark protection mechanisms on the Internet is still relevant, due to the uncertainty as to the priority of the form of protection of 
infringed rights on the Internet, as well as, the lack of a uniform mechanism of its protection at the level of legal regulation, as well as, the lack of a unified approach to solve this issue, from a management and technical side, the widespread nature of IPR infringements on the Internet, by emergence of new cases of liability, the early stage of testing and enforcement practice in this area. Today it is insufficiently precisely determined at the legislative level, as well as in the sphere of enforcement law, what is proper use of the trademark on the Internet, the concept of commercial use of a trademark on the Internet, the volume of the proper use of the sign.

Thus, problems of complex regulation of relations on the use of trademarks on the Internet, coverage of questions about the forms and types of use of signs on the Internet, forms and types of violations of rights to them, liability and ways of protection of trademark rights on the Internet, remained out of the attention of scholars of modern domestic legal science.

Analysis of recent researches and publications. In the modern science of intellectual property law there has not yet been a comprehensive study of legal regulation of trademark protection on the Internet. However, common issues, related to the existence of intellectual property and its rights on the Internet, were explored by such scientists as G. Peter Albert (Peter Albert, 1999), Babkin S.A. (Babkin, 2006), in the work of Pastukhov O.M. (Pastukhov, 2004) on copyright and related rights on the Internet. Common issues of trademark protection on the Internet have been investigated in the writings of such scholars, as Demchenko T.S. (Demchenko, 2004), Kalyatin V.O. (Kalyatin, 2010), Resenchuk V.M. (Resenchuk, 2005), Suzanne Slovakova (Zuzana Slovakova, 2008), Tishkova M.V. (Tishkova, 2010), Cherepov L.V. (Cherepov, 2007), Sheveleva T.M. (Sheveleva, 2005). The issues of legal regulation of the use of Internet domain names and problems of resolving their conflicts with trademarks have been the subject of complex research by Boyko D.V. (Boyko, 2005), Bontlab V.V. (Bontlab, 2006), Maidanyk R.A. (Maidanyk, 2009), Maidanyk N.I. (Maidanyk, 2009), Sergo A.G. (Sergo, 2005). Issues of legal protection of the means of individualization on the Internet and resolution of conflicts between them were investigated by Zhukov A.S. (Zhukov, 2009), Sergo A.G. (Sergo, 2010). Issues of evidence of trademark infringement on the Internet were raised in separate works by Vatskovsky Yu. V. (Vatskovsky, 2007), Kuzmenko T.L. (Kuzmenko, 2009).

This study identifies current approaches to the mechanism of legislative protection of trademark rights on the Internet, current issues, that can be solved through legal influence and directions of legal regulation in this field. The study of the legislation and enforcement law practice in Ukraine in the field of trademark protection on the Internet has been carried out.

Presenting main material. For the regulation the relations in the field of trademark protection on the Internet at the level of individual countries, it is applied traditional principles to determine the existence of rights, the priority of use and for the establishing the similarity and likelihood of confusion. 
The most advanced in this area should be considered U.S. law, in particular the Lanham Act of 1946 with amendments (15 USC Chapter 22), which contains the following provisions that are applicable to the use of trademarks on the Internet:

civil liability for violation of trademark rights (§ 1125 (a)),

methods of protection in the case of dilution of trademark (§ 1125 (c)),

measures of cyberpiracy prevention (§ 1125 (d)).

The last norm was adopted by the Anticybersquatting Consumer Protection Act (ACPA) in 1999 and requires that the registration of the domain name will not infringe trademark rights, provides protection against cybersquatting.

In general, at the regional level and at the level of individual countries the use and protection of trademarks on the Internet is governed by the laws on the protection of trademarks, which are amended and supplemented in accordance with the requirements of technological development and considering requirements of international standards and norms. At this stage, in view of above stated, and as a result of study of the legislation of foreign countries and regions, including the EU and USA, and enforcement law practice, as well as a number of international initiatives, regarding the improvement of regulation on the Internet, in particular searching for ways of preventing conflicts between the owners of trademarks and the owners of domain names (Update on Trademark-Related aspects of the Expansion of the Domain Name System. Standing Committee on the Law of Trademarks, Industrial Designs and Geographical Indications), we can conclude about the need to improve the Ukrainian legislation in this area.

In the case of infringement of the trademark rights on the Internet, according to the legislation of Ukraine, the main thing is to establish the owner of the content, that harms legal rights and interests. In Ukraine, there is Ukrainian network information center (UNIC), which is a domain administrator for the Ukrainian Internet segment. Within this organization, the Center of Competence Address Space of the Internet was established, whose activity is mainly aimed at protecting the rights on the Internet. Because, due to the large number of such requests and court rulings, as well as the fact that the responses to them are provided free of charge, the UNIC is not able to process them in a timely manner. In this regard, and in order to promote the protection of the rights of persons against violations on the Internet, UNIC has accredited and reaffirmed the competence of the Ukrainian Center for Support of Numbers and Addresses on the Internet, for:

- conducting the fixing and investigation of the content of web pages on the Internet with the issuance of Expert conclusions;

- issuance certificates with information about website owners or installation information.

From May 08, 2019 the Subsidiary «Center of Competence Address Space of the Internet» was started, the decision of which was made by the Ukrainian Center for Support of Numbers and Addresses (founder) on April 26, 2019 in order to further develop the project of the Center of Competence. 
Ukrainian law enforcement practice states, that in resolving disputes, related to the violation of intellectual property rights, the court must determine, whether the website and the information on it, belongs to the defendant, and also establish evidences, confirming the infringement of its intellectual property rights on the Internet. The person, whose rights have been violated, may use the services of the Center of Competence Address Space of the Internet, which conducts the fixing and research of the content of web pages on the Internet with the issuance of expert opinions (https://web-fix.org/services/ certificate-about-owner-website/).

Considering provisions of legislation and practice in the field of protection of trademarks on the Internet, that exist in the foreign countries and regions, we can offer the following recommendations for the protection of trademarks on the Internet for Ukraine.

Regarding changes into legislation. Availability of appropriate norm in the Law of Ukraine «On Protection of Rights for Sign for the Goods and Services» (Article 16, point 4), recognizing, that application of trademark on the Internet as one of the way of the use of trademark, is sufficient to provide adequate protection and filing a lawsuit.

The statement of such provision in a sufficiently general form allows us to incorporate to the infringements of trademark rights on the Internet a wide range of actions. However, it is necessary to clarify the concept of the proper use of trademarks on the Internet into Ukrainian legislation, the concept of commercial use of a trademark on the Internet, the volume of proper use of trademark, the methods and conditions of such use, the sufficiency of nominal use; the need to use it in connection with the goods and services; the concept of bona fide user and conditions of fair use; as well as conditions that exempt from liability, etc. This will improve the legal support and application of protection measures of violated rights to trademarks on the Internet by both, right holders and by judges. It would be useful to identify certain types of offenses and to delineate the types of liability for infringement of trademarks on the Internet, as well as, to provide separate provision on measures for the protection of trademark rights against cybersquatting.

For the prevention of the abusive registration of domain names as trademarks is eligible to include to the Guidelines for the Consideration of the Application for a Certificate of Ukraine to Sign for the Goods and Services (or to the corresponding Rules) commentary on the possibilities and conditions for registration of domain names as trademarks.

It was interesting to study the question on the feasibility of setting in The UA. Domain Policy (item 3) provision that second-level private domain name shall be delegated exclusively on condition, that the registrant submits the documents to the current registrar, confirming trademark rights, if it wholly or partly coincides with the trademark, etc. This provision was a different reading. In general, the practice of registering domain names in domain. UA is based on the requirement of registration of trademark as a condition of the delegation of domain name in this area for all cases. 
The experience of foreign countries, embodied in the relevant documents: The Terms and Conditions of Domain Names Registration in domains.RU and.PФ, approved by the decision of the Coordination Center for TLD RU from 05.10.2011 № 2011-18/81, and the Concept of registration of the second level domain in domains.PФ from June 17, 2009 for registration in the Cyrillic segment of the Internet, the Commission Regulation (EC) № 874/2004 of 28 April 2004, laying down public policy rules concerning the implementation and functions of the.EU Top Level Domain and the principles governing registration, the U.S. experience for delegation domains in the domain.US, indicates on existence of other approaches to solving the problem, that arise in the process of delegation of ccTLDs. In addition, existing public opinion indicates, that the requirement of providing legal documents for confirmation of trademark rights, as a condition of registration of the corresponding domain in the domain. UA, does not provide proper and effective protection against infringement of trademark owners rights and is not an obstacle for other kinds of abuse in this area. For example, some administrators of domain names simplify the procedure of domain names registration, allowing registrants to only choose a domain name, enter the number of the Trademark Certificate and pay the bill, everything else, including obtaining copies of documents from State Enterprise «Ukrainian Institute of Industrial Property», is to be performed by administrators, thus these actions create the possibility of registration of domain names in the domain.UA without the knowledge of trademark owners. In general, members of domain name registration market believe, that with the abolition of binding to the trademark to sue domain name from cybersquatters will be easier (Vlasenko, electronic resource). On this bases, considering the international and foreign practice, when introduced of new top-level domains with the aim to ensure compliance with earlier rights it is advisable to introduce a phased-registration of domain names in a specified area. Owners of earlier rights should be given priority for a certain period for registration of their domain names in a specified area. Following registrations should take place in accordance with the principle of priority in time. Furthermore, to overcome potential conflicts between trademarks and domain names, it is advisable to establish Trademark Clearinghouse and introduce service, which gives a trademark owner an opportunity for a fee, to preemptively register an exact match of its mark as a domain name to those trademarks, for which current use can be demonstrated, and service, which gives a trademark owner an opportunity to make a notice to a potential domain name registrant about the existence of a potentially conflicting trademark right, the last one should be applied for trademarks, that have evidence of current use and its effect is limited to a certain period.

As to enforcement law practice of Ukraine in the sphere of dispute resolution in the case of trademarks infringement on the Internet, it develops in a special way, than foreign one, considering statement of material Ukrainian legislation about, what is deemed to be a trademark use on the Internet and violation of trademark rights. Claims 
in such cases are formulated mainly in general terms - to prohibit the use of sign on the Internet, sometimes the specification is made as to the prohibition of the use in advertising on the web-site and as a part of domain names (Decision of The Supreme Arbitration Court of Ukraine № 21/71 from March 14, 2006, Decision of The Supreme Arbitration Court of Ukraine № 37/165-06 July 10, 2007, Decision of The Supreme Arbitration Court of Ukraine № 3/84 from January 18, 2011, electronic resource). Quite often, acts, that violate trademark rights on the Inetrnet, can be classified in different ways: as a kind of violation of the right to this object or other offense. Therefore, it is necessary to continue to study domestic judicial practice in cases of trademark infringement on the Internet and to formulate doctrinal provisions on the possible types of trademark infringements on the Internet, grounds for indemnity against liability, the nominal and fair use of trademark on the Internet.

Also it can appear the necessity to address the issue of liability of providers of online services for infringement of trademark rights on the Internet. The peculiarities of resolving this issue is caused by the national interests of the state. It seems to be acceptable to introduce the system «takedown and notice» by operators of onlineservices for trademark owners use and system of filtration of unfair actions.

It should be emphasized the need to improve administrative procedures of protection of trademarks owners rights on the Internet. In general, the system of trademarks rights protection on the Internet involves self-defense, the adoption of organizational, technical and administrative measures by search engine or by operator of onlineservices, as well as administrative and judicial procedures.

The uniform procedures, proposed at the international level (for example, by WIPO) should be provided in Ukraine in the nearest future: the pre-delegation dispute resolution mechanism, that provides a procedure for filing objections on the basis of the legal rights; the post-delegation dispute resolution mechanism, that provides a procedure for filing complaints to the registrar on the basis of generic top-level domains; an opportunity for a trademark owner for a fee to preemptively register an exact match of its mark as a domain name; the procedure of notice to a potential domain name registrant on the existence of a potentially conflicting trademark right; expedited domain name suspension mechanism.

Conclusion. Thus, in Ukraine has not been yet adopted a Legal Act, that would envisage ways and methods of protection of intellectual property rights on the Internet. In Ukraine, as in other countries, except for organizational, technical and administrative measures and procedures, is only developing a universal mechanism of protection of IPR on the Internet, that would provide for both, administrative and judicial procedure of protection of rights in such cases. Within the framework of procedures of protection of rights and elimination of the specified type of offenses, the functions of responding and providing assistance in such cases are today delegated to the Center of Competence Address Space of the Internet (https://web-fix.org/), whose services usually use in the context of litigation. Empowering online service for trademark owners, that allows them to respond the misuse of their signs on the Internet and filter out the web-resource is seemed to be also very effective. 


\section{REFERENCES}

1. Albert, G. Peter, (1964). Intellectual property law in cyberspace. BNA Books, Washington, 1999.

2. Babkin, S.A. (2006). Intellectual property in the Internet. Moscow: Center of JurInfoR, 512 p. [in Russian].

3. Bontlab, V.V. (2006). Civil law regulation of domain names: Author's abstract. dissertation... Ph. D. in Law: 12.00.03 / Kyiv National University by T. Shevchenko. Kyiv, 20 p. [in Ukrainian].

4. Boyko, D.V. (2005). The legal nature of Internet domain names. Disertatsiya kandidata yurid. nauk: 12.00.03, National Law Academy of Ukraine by Yaroslav the Wise. Kharkiv, 19 p. [in Ukrainian].

5. Certificates with information about website owners or installation information (2019). Retrieved from https://web-fix.org/послуги/довідка-провласника-веб-сайту. [in Ukrainian].

6. Cherepov, L. (2007). How to protect a trademark on the Internet. Law Gazette. Feb 8. № 6. P.12. [in Ukrainian].

7. Pastukhov O.M. (2004). Copyright on the Internet: Educ. manual. K.: School, 143 p. [in Ukrainian].

8. The Concept of registration of the second level domain in domains.РФ from June 17, 2009. Retrieved from: http://wwhois.ru/news-conceptionrf.html. [in Russian].

9. Demchenko T.S. (2006). Trademark protection (comparative legal analysis): monograph. Kyiv. Press of Ukraine, 181 p. [in Ukrainian].

10. Decision of The Supreme Arbitration Court of Ukraine № 21/71 from March 14, 2006. Retrieved from: http://vgsu.arbitr.gov.ua/docs/28_1207087.html. [in Ukrainian].

11. Decision of The Supreme Arbitration Court of Ukraine № 37/165-06 July 10, 2007. Retrieved from: http://vgsu.arbitr.gov.ua/docs/28_1632013.html. [in Ukrainian].

12. Decision of The Supreme Arbitration Court of Ukraine № 3/84 from January 18, 2011. Retrieved from: http://vgsu.arbitr.gov.ua/docs/28_3099177.html. [in Ukrainian].

13. Has there been a Sunrise period for.eu IDNs? (2012) Retrieved from: http://www.eurid.eu/en/faq\#IDN_sunrise.

14. Kalyatin, V.O. (2010). Violation of the Exclusive Right to a Trademark «Under Other Addressing Methods». Intellectual property. Copyright and related rights. № 3. P. 16-26. [in Russian].

15. Kuzmenko, T. (2009). Protecting a Trademark on the Internet. Law Journal: analytical materials, commentary, case law. 2009. № 11 (89). P. 105-108. [in Ukrainian].

16. Maidanyk, R.A. (2009). The Right to Domain Name on the Internet. Kyiv. All-Ukrainian. association. Legal Unity. № 2.384 p. [in Ukrainian].

17. Maidanyk, N. (2009). The Right to Domain Name on the Internet: Concepts and Legal Nature. Legal Ukraine. № 6. P. 81-86. [in Ukrainian].

18. Maidanyk, N. (2009). Exercising the Domain Name Right on the Internet. Legal Ukraine. № 7. P. 62-67. [in Ukrainian]. 
19. Resenchuk, V. (2005). Trademarks on the Internet: Problems of Legal Regulation in Ukraine. Intellectual property. № 12. P. 26-29. [in Ukrainian].

20. Sergo, A. (2005). Ways to resolve conflicts, arising from the use of domain names on the Internet. Intellectual property. № 2. P. 31-40. [in Russian].

21. Sergo, A. (2010). The use of individualization in domain names: the practice of the WIPO Arbitration Center. Intellectual Property. Industrial property. 2010. № 11. P. 38-51. [in Russian].

22. Sheveleva, T. (2005). Well-known trademarks in the light of modern information technologies. Intellectual property. № 4. P. 13-19. [in Russian].

23. The Terms and Conditions of Domain Names Registration in domains.RU Retrieved from: http://www.cctld.ru/en/docs/rules.php. [in Russian].

24. Tishkova, M. (2010). Least-studied aspects of the problem of legal regulation of protection of TM on the Internet. Intellectual property. Copyright and related rights. № 1. P. 21-31. [in Russian].

25. Update on Trademark-Related aspects of the Expansion of the Domain Name System. Standing Committee on the Law of Trademarks, Industrial Designs and Geographical Indications. Twenty-Seventh Session, Geneva, September 18 to 21, 2012. SCT/27/8, July 18, 2012. 7 p. Retrieved from: http://www.wipo.int/edocs/mdocs/ sct/en/sct_27/sct_27_8.

26. 15 USC Chapter 22 - TRADEMARKS. Retrieved from: http://www.law.cornell. edu/uscode/text/15/chapter-22.

27. Vatskovsky, Yu. (2007). Features of the evidence in the event of a dispute about the collision of rights to the means of individualization with the rights to the domain name. Intellectual property. Industrial property. № 9. P. 60. [in Russian].

28. Vlasenko, V. Lawlessness in domain.UA. Retrieved from: http://www. warning.dp.ua/comp18.htm. [in Russian].

29. What exactly has the EU done to create the.eu TLD? (2012). Retrieved from: http://ec.europa.eu/information_society/policy/doteu/frequently_new/index_ en.htm.

30. What makes us so different? (2012). Retrieved from: http://www.rwgusa. $\mathrm{com} / \mathrm{biz} /$ domain_name_registration_rules.htm.

31. Zhukov, A. (2009). Legal basis of conflict prevention between the means of individualization and entrepreneurship on the Internet. Intellectual property. Copyright and related rights. 2009. № 4. P. 31-38. [in Russian].

32. Zuzana Slovakova (2006). Protection of trademarks and the Internet with respect to the Czech Law. Journal of International Commercial Law and Technology. Vol. 1. Issue 2. P. 72-79.

33. Zuzana Slovakova (2008). International Private Law Issues regarding Trademark Protection and the Internet within the EU. Journal of International Commercial Law and Technology. Vol. 3. Issue 1. P. 76-83. 